\title{
The role of religiosity on the relationship between task complexity, experience and audit judgement
}

\author{
Intan Bunga Pertiwi, ${ }^{1}$ Taufikur Rahman² \\ 1,2Institut Agama Islam Negeri Salatiga, Indonesia \\ email: intanbungap.asfebi@gmail.com
}

\begin{abstract}
Purpose - The purpose of the study is to examine the effect of task complexity and experience on audit judgment with religiosity as moderator on the auditors of the Inspectorate of Semarang Regency and Salatiga City.
\end{abstract}

Method - The data collection of this research was primary by using a questionnaire. The population in this study were all auditors of the Inspectorate of Semarang Regency and Salatiga City. The selection of samples in this study used the purposive sampling technique and selected 45 auditors. The data was processed using IBM Statistics SPSS version 23. The data analysis in this study included the research instrument test (validity and reliability test), classical assumption test (normality, heteroscedasticity, and multicollinearity test), F-test, t-test, and MRA test.

Result - The results showed that task complexity and experience partially had a positive and significant effect on audit judgment. The MRA test showed that religiosity did not moderate the effect of task complexity and experience on audit judgment in the auditors of the Inspectorate of Semarang Regency and Salatiga City.

Implication - It is expected that auditors consider the religiosity in making auditjudgment.

Originality - This research is the first study that uses religiosity as a moderator in the relationship between task complexity and experience on auditjudgment.

Keywords: tax complexity; experience; religiosity; auditjudgement 
Intan Bunga Pertiwi, Taufikur Rahman

\section{Introduction}

The importance of regional financial supervision is to ensure that all regional economic resources are used for the benefit of the community and

JIAFR | 274 can be accounted for according to the principles of accountability and transparency (Artha et al., 2014). For this purpose, the Regional Inspectorate is tasked with carrying out internal government oversight by conducting regular inspections of the Regional Apparatus Work Units (SKPD) (Artha et al., 2014). In accordance with their main duties and functions as internal auditors, the Inspectorate staff conducts regular inspections of the Regional Apparatus Work Units. After completing the inspection, the inspectorate compiles and publishes an inspection report (LHP) which is the result of examining evidence not only in the form of regional losses but also in terms of administrative arrangements, both aspects of apparatus management and the implementation of tasks and functions (Alamri et al., 2017).

Audit, which is a part of supervision, in practice, consists of seeking information about what carried out in the examined agency, comparing the results with the specified criteria, and approving or rejecting the results by providing recommendations on corrective actions. As stated in the Professional Standards of Public Accountants (SPAP) section 341, when the examination process is running, the auditor will express an opinion with judgment based on the phenomena that exist in a business unit. Audit judgment is an auditor's policy that refers to the entire audit process in order to determine an opinion (Pektra \& Kurnia, 2015). Today's society really expects the government's internal supervisory apparatus to take more roles from merely recommending corrections and correcting errors, to be able to prevent fraud in the implementation of the government. Therefore, this study was conducted to analyze how the audit judgment or judgment on auditors of the Inspectorate of Semarang Regency and Salatiga City Inspectorate is.

Audit judgment is influenced by limitations on the scope or time of the audit, while non-technical factors such as gender, obedience pressure, task complexity, experience, knowledge, and so on are considered as aspects of 
individual behavior that can affect audit judgment (Yustrianthe, 2012). The existence of complex tasks with a certain level of complexity can affect someone in carrying out these tasks. Research by Alamri et al. (2017) and Azizah \& Pratono (2020) explain that task complexity has a significant positive effect on audit judgment. In contrast, research by Riantono (2018) JIAFR | 275 and Gendrianto et al. (2018) said that task complexity did not affect audit judgment. While research by Surya et al. (2018), Putri (2018), and Sari \& Ruhiyat (2017) explain that task complexity has a significant negative effect on audit judgment. This means that the higher the complexity of the tasks faced by the auditor, the less precise the audit judgment will be.

In addition to the complexity of the task, work experience is also one of the factors that influence the judgment of an auditor. Based on their experience, auditors learn how to make the right decisions (William \& Anton, 2019). Research by Riantono (2018), Gendrianto et al. (2018), and Parwatha et al. (2017) show that work experience has a significant positive effect on audit judgment. In contrast, the research of Putra \& Rani (2016), Alamri et al. (2017) stated that the auditor's work experience did not affect audit judgment. Little or much work experience of an auditor does not have any effect on audit judgment.

The existence of other factors that affect the relationship between the independent variable and the dependent variable is suspected to be the cause of the inconsistent results of previous studies (Surya et al., 2018). As an update, this research adds religiosity as a moderator in the relationship between task complexity and experience on audit judgment. Religion, according to Nazaruddin (2011) in Surya \& Dewi (2019) is an integrated system and belief, a lifestyle that gives meaning to human life and directs it to sacred values or the highest values. In other words, a person will have good attitudes and behavior if he/she has high religiosity or belief. Likewise, an auditor will carry out his/her responsibilities properly. It is hoped that this research will provide results that support or do not support the theory, as well as confirm previous studies. So, the purpose of this study are: 1) to find out the effect of task complexity on audit judgment, 2) to find out the effect of 
experience on audit judgment, 3) to find out the effect of task complexity on audit judgment moderated by religiosity, and 4) to find out the effect of experience audit judgment moderated by religiosity.

\section{JIAFR | 276 Literature Review}

\section{$X$ and YTheory}

Theories X and Y put forward by Douglas McGregor explain different views about humans (Sari, 2016). Type $X$ shows a negative individual tendency where he does not like work and avoids responsibility. When under pressure or a complex assignment, type $\mathrm{X}$ is more likely to make an inappropriate judgment because the individual is looking for a safe way to make a judgment (Saud et al., 2018). In contrast, type Y auditors prioritize work and they are responsible, able to control themselves, innovative, and goal-oriented. Type $\mathrm{Y}$ individuals emphasize attitude and can make judgments as they should. Audit judgment in terms of Theory X (negative) and $Y$ (positive) is influenced by several factors including task complexity and work experience.

\section{Audit Judgement}

Judgment is a process of obtaining information, choosing to act or not to act, and receiving further information (Jamilah et al., 2007 in Wibowo, 2010). The auditors must hold their responsibility not only to the opinion on the financial statements but also to the results. Auditors must be careful in making their judgments.

\section{Task Complexity}

Task complexity is an unstructured task (Wibowo, 2010). According to Kahneman et al. (2011) in William \& Anton (2019) task complexity means very difficult tasks or complex structures. The complexity of the task indicates the level of innovation and audit consideration required by the auditor in each accepted task (William \& Anton, 2019). Given the wide range of work or services that can be provided to clients, it is likely for auditors to face 
problems of complex with varied complexity to provide the proper assessment and avoid mistakes due to complex tasks.

\section{Experience}

Auditor's work experience is the experience the auditor has in examining JIAFR | 277 in terms of the length of work and the number of tasks that have been carried out (Putri, 2018). Professional judgment is the result of several factors such as knowledge, competence, and others but the most prominent to control all elements such as experience is the auditor's feeling in dealing with the situation by remembering the success of the previous situation (Wibowo, 2010). Experience makes auditors accustomed to situations and circumstances in each assignment and based on that experience the auditors can learn how to make a judgment (Sulistyawati et al., 2019).

\section{Religiosity}

Religiosity is a belief, spiritual lifestyle, ritual activity that upholds sacred values based on the beliefs held by the auditor (Surya \& Dewi, 2019). According to Barnet et al. (1996) in Surya et al. (2018), religiosity is concerned with: cognitive (religious knowledge and beliefs), influence (emotional bonds or feelings), and behavior (religious practices). Religiosity can affect a person's morale and contribute to idealism (Surya \& Dewi, 2019). People who have faith are required to check every piece of information they receive so that it is proven to be true according to the facts. Likewise, an auditor must examine the financial statements based on the available evidence carefully to provide the right judgment as the financial statements are presented.

\section{Hypothesis Development}

\section{Effect of Task Complexity on Audit Judgement}

According to Kahneman et al. (2011) in William \& Anton (2019), task complexity means a very difficult task or a complex task structure. A person's performance and quality at work are influenced by the complexity of the 
work being carried out. The inaccuracy of an auditor's decision or judgment is the result of errors that occur. In addition, auditors are likely to encounter complex and varied problems considering the many fields of work and services that can be provided to clients. As stated in the research of Surya et al. (2018), Putri (2018), and Sari \& Ruhiyat (2017) that the more complex the tasks received by the auditors, the lower or less precise audit judgments result. Based on the explanation above, the first hypothesis of this research is:

$H_{1}$ : Task complexity has a negative and significant effect on audit judgment

\section{Effect of Work Experience on Audit Judgement}

Auditor's work experience is the experience the auditor has in examining in terms of the length of work and the number of tasks that have been carried out (Putri, 2018). Experience is judged to affect the assessment of the auditor's work. The number of inspections has been carried out or the number of companies that have been audited is also an aspect of the auditor's work experience. The more experienced an auditor is, the more proficient and accustomed an auditor is in evaluating evidence and information, whether relevant or not, that supports his/her assignment, including in giving judgment (Yustrianthe, 2012). According to the research of Saud et al. (2018), Putri (2018) and Sari (2016) work experience has a significant positive effect on audit judgment. Based on the description above, the second hypothesis in this study is:

\section{$\mathrm{H}_{2}$ : Work experience has a positive and significant effect on audit judgment}

\section{The Effect of Task Complexity on Audit Judgement with Religiosity as Moderator}

As described above, the more complex the tasks received by the auditor will result in a decreased or inaccurate judgment. Praditaningrum (2012) in Surya et al. (2018) argues that when auditors face complex situations, they will prioritize a safer path than work and even behave dysfunctionally in 
making judgments. Religiosity can affect a person's moral standards. In other words, auditors who have high religiosity will have high ideals and empathy so that they pay attention to the interests of others. That way the judgment given will be better. Based on the description above, the third hypothesis of this study is:

$H_{3}$ : Religiosity moderates the effect of task complexity on auditjudgment

\section{The Effect of Work Experience on Audit Judgement with Religiosity as Moderator}

The auditors' work experience is counted from the length of time they have worked as an auditor and the number of examinations that have been carried out. The more experienced an auditor is, the more accurate the judgment will be. As explained above, religiosity can affect a person's moral standards. As the auditors' experience increases and is balanced by high religiosity, they will be increasingly responsible for their work. In other words, they will be more careful when giving their judgment. Based on the description above, the fourth hypothesis in this study is:

$H_{4}$ : Religiosity moderates the effect of work experience on audit judgment

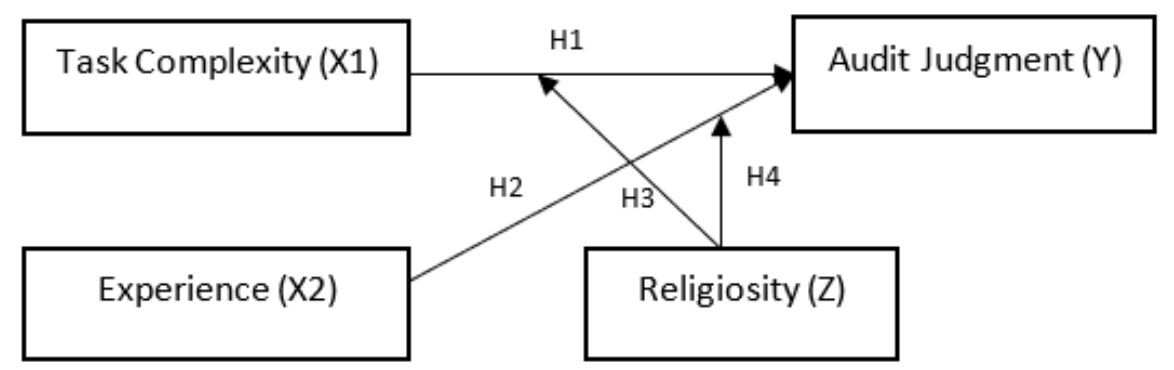

Figure 1. Research Framework 


\section{Research Methods}

This research is quantitative. The objects of this research are the auditors at the Inspectorate of Semarang Regency and Salatiga City. The population in this study is shown in table 1 . The sampling in this study used the purposive sampling technique. The sample criteria in this study include 1) Auditors who have already conducted audits. 2) Auditors who have worked for two years or more. A summary of the number of samples and the rate of return of the questionnaire is presented in the table 2 .

The type of data used in this study is primary data using a questionnaire. The measurement scale used is a Likert scale with a 5-point scale as follows: 1 - Strongly disagree, 2 - Disagree, 3 - Neutral, 4 - Agree, 5 - Strongly agree.

Table 1. List of Agencies

\begin{tabular}{|c|c|c|c|}
\hline No & Agency & Address & Population \\
\hline 1 & $\begin{array}{l}\text { Semarang Regency } \\
\text { Inspectorate }\end{array}$ & $\begin{array}{l}\text { Sidomulyo Street, East Ungaran } \\
\text { District, Semarang Regency }\end{array}$ & 40 \\
\hline 2 & $\begin{array}{l}\text { Salatiga City } \\
\text { Inspectorate }\end{array}$ & Cemara Street No. 38, Salatiga & 21 \\
\hline
\end{tabular}

Table 2. Number of Respondents and Questionnaire Return Rates

\begin{tabular}{lcc}
\hline \multicolumn{1}{c}{ Information } & Number & Percentage \\
\hline $\begin{array}{l}\text { Number of } \\
\text { questionnaires } \\
\text { distributed }\end{array}$ & 61 & $100 \%$ \\
\hline $\begin{array}{l}\text { Number of non- } \\
\text { returned } \\
\text { questionnaires }\end{array}$ & 14 & $22.95 \%$ \\
\hline $\begin{array}{l}\text { Number of returned } \\
\text { questionnaires }\end{array}$ & 47 & $77.05 \%$ \\
\hline $\begin{array}{l}\text { Number of } \\
\text { questionnaires } \\
\text { processed }\end{array}$ & 45 & $95.75 \%$ \\
\hline
\end{tabular}


The role of religiosity on the relationship between ...

Table 3. Definition and Indicators of the Variables

\begin{tabular}{|c|c|c|}
\hline Variable & Definition & Indicator \\
\hline Complexity Task & $\begin{array}{l}\text { a task that is unstructured, } \\
\text { difficult to understand, } \\
\text { ambiguous, and related to } \\
\text { one another (William \& } \\
\text { Anton, 2019) }\end{array}$ & $\begin{array}{l}\text { task difficulty level: limited } \\
\text { certainty, limited memory and } \\
\text { integrate, limited ability to } \\
\text { problems } \\
\text { Clarity of information: multiple } \\
\text { task, different task, and } \\
\text { interrelated task (Pangesti \& } \\
\text { Setyowati, 2018 and William \& } \\
\text { Anton, 2019) }\end{array}$ \\
\hline Experience & $\begin{array}{l}\text { Auditor work experience is } \\
\text { the experience of the auditor } \\
\text { in examining in terms of the } \\
\text { length of work and the } \\
\text { number of tasks that have } \\
\text { been carried out (Putri, 2018) }\end{array}$ & $\begin{array}{l}\text { the length of work as an } \\
\text { auditor, the number of tasks } \\
\text { performed or the number of } \\
\text { companies faced, knowledge } \\
\text { gained, length of time in } \\
\text { carrying out tasks, expertise, } \\
\text { and skills or sensitivity in } \\
\text { dealing with a problem } \\
\text { (Yustrianthe, 2012) }\end{array}$ \\
\hline Religiosity & $\begin{array}{l}\text { a belief, spiritual lifestyle, } \\
\text { ritual activity of a person who } \\
\text { upholds sacred values based } \\
\text { on the beliefs that are owned } \\
\text { or adhered to (Surya \& Dewi, } \\
\text { 2019) }\end{array}$ & $\begin{array}{l}\text { ideological beliefs, religious } \\
\text { practices, religious experience, } \\
\text { religious knowledge, and } \\
\text { commitment to religious } \\
\text { teachings (Suryaningsih, 2019) }\end{array}$ \\
\hline Judgment Audit & $\begin{array}{l}\text { the auditors' policy in } \\
\text { determining their opinion } \\
\text { which refers to the entire } \\
\text { audit process carried out } \\
\text { (Pektra \& Kurnia, 2015). }\end{array}$ & $\begin{array}{l}\text { the influence of the client, the } \\
\text { influence of superiors, and the } \\
\text { determination of the level of } \\
\text { materiality (Gendrianto et al., } \\
\text { 2018) }\end{array}$ \\
\hline
\end{tabular}

The definition of variables and measurement indicators to obtain data in this study is described in the table 3 . This study uses primary data in the form of a questionnaire. The analytical tool used is the IBM SPSS Statistics 23 data processing program. SPSS (Statistical Package for Social Sciences) is a 
Intan Bunga Pertiwi, Taufikur Rahman

Windows-based software that is useful for analyzing data, performing statistical calculations both parametric and non-parametric (Perdana $\mathrm{K}$, 2016). In this study, the data were processed with several tests including the research instrument tests, namely the validity test and reliability test, classical assumption test (normality test, multicollinearity test, and heteroscedasticity test), F-test, t-test, and MRA test.

\section{Results and Discussion}

Table 4. Respondent Criteria

\begin{tabular}{lccc}
\hline \multicolumn{1}{c}{ Criteria } & Information & Number & Percentage (\%) \\
\hline Agency & Semarang Regency Inspectorate & 32 & 71.1 \\
& Salatiga City Inspectorate & 13 & 28.9 \\
\hline Age & $23-32$ & 11 & 24.4 \\
& $33-41$ & 12 & 26.7 \\
& $42-50$ & 9 & 20 \\
& $51-59$ & 13 & 28.9 \\
\hline Gender & Male & 22 & 48.9 \\
& Female & 23 & 51.1 \\
\hline Graduate & D3 & 2 & 4.4 \\
& S1 & 29 & 64.4 \\
& S2 & 14 & 31.2 \\
\hline Length of & S3 & 0 & 0 \\
service & $2-10$ years & 28 & 62.2 \\
Position & Over 10 years & 17 & 37.8 \\
& Junior Auditor & 19 & 42.2 \\
& Senior Auditor & 19 & 42.2 \\
\hline
\end{tabular}

Source: processed primary data 2021

Table 5. Descriptive Statistics

\begin{tabular}{lcccccc}
\hline \multicolumn{1}{c}{ Variable } & Mean & Median & Modus & Max. & Min. & TCR \\
\hline Task complexity & 24.22 & 24 & 24 & 30 & 15 & 80.73 \\
Experience & 24.16 & 24 & 24 & 30 & 20 & 80.53 \\
Religiosity & 22.73 & 24 & 25 & 25 & 18 & 90.92 \\
Audit Judgment & 12.2 & 12 & 12 & 15 & 11 & 81.33 \\
\hline
\end{tabular}

Source: processed primary data 2021 
Table 6. Validity Test Results

\begin{tabular}{|c|c|c|c|c|}
\hline Variable & Instrument & $r_{\text {count }}$ & $\mathbf{r}_{\text {table }}$ & Validation \\
\hline Task & 1 & 0.639 & \multirow{6}{*}{0.304} & \multirow{6}{*}{ Valid } \\
\hline \multirow[t]{5}{*}{ Complexity } & 2 & 0.733 & & \\
\hline & 3 & 0.851 & & \\
\hline & 4 & 0.823 & & \\
\hline & 5 & 0.766 & & \\
\hline & 6 & 0.705 & & \\
\hline Work & 1 & 0.670 & \multirow{6}{*}{0.304} & \multirow{6}{*}{ Valid } \\
\hline \multirow[t]{5}{*}{ Experience } & 2 & 0.697 & & \\
\hline & 3 & 0.792 & & \\
\hline & 4 & 0.699 & & \\
\hline & 5 & 0.713 & & \\
\hline & 6 & 0.597 & & \\
\hline \multirow[t]{5}{*}{ Religiosity } & 1 & 0.870 & \multirow{5}{*}{0.304} & \multirow{5}{*}{ Valid } \\
\hline & 2 & 0.843 & & \\
\hline & 3 & 0.879 & & \\
\hline & 4 & 0.905 & & \\
\hline & 5 & 0.770 & & \\
\hline Audit & 1 & 0.779 & \multirow{3}{*}{0.304} & \multirow{3}{*}{ Valid } \\
\hline \multirow[t]{2}{*}{ Judgement } & 2 & 0.835 & & \\
\hline & 3 & 0.786 & & \\
\hline
\end{tabular}

Source: processed primary data 2021

From the table 5, it can be seen that the respondent's level of achievement for task complexity and experience is in the good category. Meanwhile, religiosity and audit judgment got very good category.

Validity shows the accuracy of the measuring instrument to carry out the function (Rahman \& Solikhah, 2016). The results of the validity of this study can be seen in table 6 . Table 6 shows that every instrument in this research has $r_{\text {count }}>r_{\text {table. }}$ This result shows all instruments are valid. 
A reliability test can be used to show whether the result can be trusted and consistent or not (Al Umar \& Zuhri, 2019). The results of this variable are presented in table 7 . Table 7 shows the result of the reliability test with Cronbach' Alpha's value of all variables is more than 0.6. It means all of the questionnaires are reliable or can be trusted as measuring instruments.

This test is used to show that the sample is taken from a normally distributed population (Perdana K, 2016). Normality test in this research used Kolmogorov Smirnov test with the result on table 8. The result of the normality test in table 8 shows the probability of more than 0.05 . It means the sample in this research is normal.

Table 7. Reliability Test Result

\begin{tabular}{lcc}
\hline \multicolumn{1}{c}{ Variable } & Cronbach's Alpha & Conclusion \\
\hline Task Complexity & 0.845 & \\
Work Experience & 0.738 & Reliable \\
Religiosity & 0.889 & \\
Audit Judgement & 0.707 & \\
\hline
\end{tabular}

Source: processed primary data 2021

Table 8. Normality Test Result

\begin{tabular}{lcl}
\hline \multicolumn{1}{c}{ Variable } & Sig. & \multicolumn{1}{c}{ Conclusion } \\
\hline $\begin{array}{l}\text { Unstandardized } \\
\text { Residual }\end{array}$ & 0.200 & $\begin{array}{l}\text { The data were normally } \\
\text { distributed }\end{array}$ \\
\hline
\end{tabular}

Source: processed primary data 2021

Table 9. Multicollinearity Test Result

\begin{tabular}{lccc}
\hline \multicolumn{1}{c}{ Variable } & Tolerance & VIF & Conclusion \\
\hline Task Complexity $(\mathrm{X})$ & 0.006 & 157.822 & There is multicollinearity \\
Experience $(\mathrm{X} 2)$ & 0.003 & 329.328 & \\
Religiosity $(\mathrm{Z})$ & 0.003 & 334.573 & \\
Interaction-X1Z & 0.003 & 339.180 & \\
Interaction-X2Z & 0.001 & 887.030 & \\
\hline
\end{tabular}

Source: processed primary data 2021 
The multicollinearity test aims to detect a correlation between independent variables (Ariawaty \& Evita, 2018). Multicollinearity in this research is shown in table 9. Table 9 shows multicollinearity between independent variables, where the tolerance values are $<1$ but the VIF values are $>10$.

JIAFR | 285

This test aims to test the inequality of the residual variance from one observation to another in a regression model (Rahman \& Solikhah, 2016). The results of heteroscedasticity test in this research are shown in table 10. The data in this research have no heteroscedasticity problems. The results are shown in table 10 and all variables have significance value more than 0.05 .

The $\mathrm{F}$ test (simultaneous test) is used to determine whether the independent variable simultaneously affects the dependent variable or not (Bawono \& Shina, 2018). The results of the $\mathrm{F}$ test are presented in table 11. Table 11 shows that $F_{\text {count }}>F_{\text {table }}$ with a significance far below 0.05 . It means that task complexity, work experience, and religiosity simultaneously have a significant effect on audit judgment.

Table 10. Heteroscedasticity Test Result

\begin{tabular}{lcc}
\hline \multicolumn{1}{c}{ Variable } & Sig. & Conclusion \\
\hline Task Complexity & 0.892 & Has no heteroscedasticity problem \\
Experience & 0.489 & \\
Religiosity & 0.059 & \\
\hline
\end{tabular}

Source: processed primary data 2021

Table 11. F Test Results

\begin{tabular}{ccc}
\hline F count & Ftabel $_{\text {tig. }}$ \\
\hline 17.006 & 3.15 & 0.000 \\
\hline
\end{tabular}

Source: processed primary data 2021

Table 12. t-Test Results

\begin{tabular}{lcccc}
\hline \multicolumn{1}{c}{ Variable } & B & $\mathbf{T}_{\text {count }}$ & $\mathbf{t}_{\text {table }}$ & Sig. \\
\hline Task Complexity & 0.199 & 3.338 & 0.304 & 0.002 \\
Work Experience & 0.343 & 5.484 & 0.304 & 0.000 \\
\hline
\end{tabular}

Source: processed primary data 2021 
Intan Bunga Pertiwi, Taufikur Rahman

Table 13. MRA Test Results

\begin{tabular}{cccc}
\hline Variable & B & tcount $_{\text {s }}$ & Sig. \\
\hline Interaction-X1Z & 0.009 & 0.350 & 0.729 \\
Interaction-X2Z & 0.012 & 0.291 & 0.773 \\
\hline Source: processed primary data 2021 & &
\end{tabular}

This test is to see the effect of the independent variable on the dependent variable partially (Rahman \& Solikhah, 2016). The results of the t-test of this study are shown in table 12 . Task complexity shows a coefficient value of 0.199 with positive parameters and $t_{\text {count }}>t_{\text {table }}$ with a significance below 0.05 . Work experience also shows a positive parameterized coefficient of 0.343 and $t_{\text {count }}>t_{\text {table }}$ with a significance far below 0.05. This means that task complexity and work experience partially have a positive and significant effect on audit judgment.

Moderated Regression Analysis or interaction test is a multiple linear regression test tool where the regression equation contains an interaction element (multiplication of two or more independent variables) (Liana, 2009). MRA aims to test the ability to moderate variables in moderating the effect of independent variables on the dependent variable (Surya et al., 2018). In this study, a pure moderator was tested by making interaction regression (Ghozali, 2013). The results of the MRA test are shown in table 13. The MRA test results in table 13 show that the significance of the $\mathrm{X} 1 \mathrm{Z}$ interaction variable is 0.729 , far above 0.05 . Thus, religiosity is not able to moderate the effect of task complexity (X1) on audit judgment. Likewise, the X2Z interaction variable shows a significance of 0.773 above 0.05 . This means that religiosity is also unable to moderate the effect of work experience (X2) on audit judgment.

\section{Task Complexity has a negative and significant effect on audit judgment}

The results of the study in table 12 show the value of tcount>ttable (3.338>0.304) with a significance of 0.002 (below 0.05 ) and a coefficient value of 0.199 with positive parameters for the task complexity variable. This 
means that the results of this study empirically indicate that task complexity has a positive and significant effect on audit judgment. That is, the higher the complexity of the tasks received by the auditor, the better the level of audit judgment given by the auditor.

The results of this study indicate that the first hypothesis, which states JIAFR | 287 that task complexity has a negative and significant effect on audit judgment, is rejected. Task complexity is the level of difficulty and complexity of a task. It is undeniable that auditors are always faced with many, different, interrelated, and confusing tasks. The analysis of the research results shows that the higher the complexity of a task received by the auditor does not necessarily make the judgments made lower. On the other hand, the auditor will give a better judgment. Because the auditor can handle and complete the complexity of audit assignments (Azizah \& Pratono, 2020). Complex tasks require auditors to develop and improve their competence in carrying out each audit process. Auditors who can deal with and overcome a high level of task complexity will provide better judgment. In other words, the auditors can understand well the tasks that must be done and how to do them.

\section{Work Experience has a positive and significant effect on audit judgment}

The results of the study in table 12 show that the work experience variable has a positive parameterized coefficient of 0.343 and tcount $>$ ttable value of $5.484>0.304$ with a significance of 0.000 which is far below 0.05 . Thus, empirically work experience has a positive and significant effect on audit judgment. This means that when the work experience of an auditor increases, the audit judgment given becomes better.

The second hypothesis (H2), which states that work experience has a positive and significant effect on audit judgment, is accepted. The experience of the auditors makes them accustomed to dealing with the situations and circumstances of each assignment so that the understanding of each assignment they undertake becomes better (Saud et al., 2018). The more experience the auditors have, the more insightful and skilled they become in performing audit tasks. The auditors will meet a variety of clients and audit 
assignments so that they will be more accustomed in dealing with various kinds of audit problems. A task that is carried out repeatedly will have the opportunity to make it a learning process to do it well (Alamri et al., 2017). As experience increases, the auditors become more skilled and careful in providing judgments on situations/conditions, problems, and audit evidence they encounter.

\section{Religiosity moderates the effect of task complexity on audit judgment}

The interaction variable $\mathrm{X} 1 \mathrm{Z}$ in table 13 is a multiplication of interaction variables between the task complexity variable and the religiosity variable. The results of the MRA test in this study indicate that the significance level of the X1Z Interaction variable is 0.729 , which is far above 0.05 . This means that empirically religiosity is not able to moderate the effect of task complexity on audit judgment. The higher the religiosity of the auditors at the Inspectorate of Semarang Regency and Inspectorate of Salatiga City are not significantly able to moderate the effect of task complexity on their audit judgment.

The third hypothesis (H3), which states that religiosity moderates the effect of task complexity on audit judgment, is rejected. This means that the judgment given is purely influenced by the complexity of the task it receives and is not supported by the level of religiosity it has. Auditors who can face and overcome the complexity of the audit assignments they receive will be able to make good judgments (Azizah \& Pratono, 2020). The auditors' responsibility lies in each audit judgment they provide. The high level of religiosity is unable to strengthen or weaken the effect of task complexity on the audit judgment given to auditors at the Inspectorate of Semarang Regency and Salatiga City. A good level of innovation and audit consideration is required in completing complex audit tasks (Azizah \& Pratono, 2020).

\section{Religiosity moderates the effect of work experience on audit judgment}

The interaction variable $\mathrm{X} 2 \mathrm{Z}$ in table 13 is a multiplication of interaction variables between the work experience variable and the religiosity variable. The MRA test results in the table show a coefficient value of 0.012 with 
positive parameters. However, the significance value of the $\mathrm{X} 2 \mathrm{Z}$ Interaction variable is 0.773 , which is above 0.05 . That is, it is empirically proven that religiosity cannot significantly moderate the effect of work experience on audit judgment on auditors at the Inspectorate of Semarang Regency and Salatiga City.

JIAFR | 289

The description above explains that the fourth hypothesis (H4), which states that religiosity moderates the effect of work experience on audit judgment, is rejected. The judgment given by the auditors is influenced by the experience they have which is not supported by the high level of religiosity they have. The experience of the auditors makes them accustomed in dealing with the situations and circumstances of each assignment so that the understanding of each assignment they undertake becomes better (Saud et al., 2018). The auditors provide judgment on each audit process they carry out by applying the guidelines and code of ethics as well as their audit insights and skills based on the experience gained, not based on the level of religiosity.

\section{Conclusion}

The results of this study indicate that: 1) Task complexity partially has a positive and significant effect on audit judgment. When the complexity of the task increases, the audit judgment will be more precise; 2) Experience has a positive and significant effect on audit judgment. The more experienced the auditors, the more accurate the audit judgment they made; 3 ) Religiosity is not able to moderate the effect of task complexity on audit judgment. Religiosity does not act as a moderator in the relationship between task complexity and audit judgment; 4) Religiosity is not able to moderate the effect of work experience on audit judgment. Religiosity does not act as a moderator in the relationship between experience and audit judgment.

Based on the research results, it is recommended to carry out performance monitoring and evaluation so that auditors can maintain and improve the good and accountable audit judgment along with increasingly complex task, increased experience, and high religiosity. It is also recommended for further research to add test samples and other 
Intan Bunga Pertiwi, Taufikur Rahman

independent or dependent variables such as obedience pressure, audit expertise, and others in order to obtain better and more accurate results.

\section{References}

JIAFR | 290 Al Umar, A. U. A., \& Zuhri, S. (2019). Pengaruh Manfaat, Pengetahuan dan Edukasi terhadap Minat Mahasiswa dalam Berinvestasi di Pasar Modal Syariah. Li Falah-Jurnal Studi Ekonomi Dan Bisnis Islam, 4(1), 129-138.

Alamri, F., Nangoi, G. B., \& Tinangon, J. (2017). Pengaruh Keahlian, Pengalaman, Kompleksitas Tugas, dan Independensi terhadap Audit Judgement Auditor Internal. Jurnal EMBA, 5(2), 593-601.

Ariawaty, R. R. N., \& Evita, S. N. (2018). Metode Kuantitatif Praktis (1st ed.). PT. Bima Pratama Sejahtera.

Artha, I. M. A. P., Herawati, N. T., \& Darmawan, N. A. S. (2014). Pengaruh Keahlian Audit, Konflik Peran dan Kompleksitas Tugas terhadap Audit Judgemenet. E-Journal S1 Ak Universitas Pendidikan Ganesha, 2(1).

Azizah, N. D. J., \& Pratono, R. (2020). Pengaruh Locus Of Control, Independensi, Kompleksitas Tugas, dan Gender Terhadap Audit Judgement. Liability, 02(1), 106-126.

Bawono, A., \& Shina, A. F. I. (2018). Processing Data Penelitian Kuantitatif Menggunakan Eviews. LP2M IAIN Salatiga.

Gendrianto, Rustandi, B., \& Mutaqien, T. Z. (2018). Faktor-Faktor yang Mempengaruhi Audit Judgment. Jurnal SIKAP, 3(1), 37-48.

Ghozali, I. (2013). Aplikasi Analisis Mulivariate dengan Program IBM SPSS 21 (P. P. Harto (ed.)). Badan Penerbit Universitas Diponegoro.

Liana, L. (2009). Penggunaan MRA dengan Spss untuk Menguji Pengaruh Variabel Moderating terhadap Hubungan antara Variabel Independen dan Variabel Dependen. Jurnal Teknologi Informasi DINAMIK, XIV(2), 90-97.

Pangesti, D. B., \& Setyowati, W. (2018). Pengaruh Persepsi Etis, Pengalam Auditor, Tekanan Ketaatan dan Kompleksitas Tugas terhadap Kualitas Audit Judgement. Prosiding SENDI_U, 737-741.

Parwatha, I. P. A., Sujana, E., \& Purnamawati, I. G. A. (2017). Pengaruh Tekanan Ketaatan, Komplesitas Tugas, Pengalaman Kerja Terhadap Audit Judgment. E-Journal S1 Ak Universitas Pendidikan Ganesha Jurusan Akuntansi Program S1, 8(2), 1-11. 
Pektra, S., \& Kurnia, R. (2015). Pengaruh Gender, Kompleksitas Tugas, Tekanan Ketaatan, Pengalaman Auditor terhadap Audit Judgement. Ultima Accounting, 7(1), 1-20.

Perdana K, E. (2016). Olah Data Skripsi dengan SPSS 22 (Christianingrum (ed.); 1st ed.). LAB KOM Manajemen FE UBB.

Putra, A. M. T., \& Rani, P. (2016). Pengaruh Gender, Kompleksitas Tugas, Pengalaman Auditor dan Kompetensi Profesional terhadap Audit Judgement. Jurnal Akuntansi Dan Keuangan, 5(2), 80-100.

Putri, A. U. (2018). Pengaruh Tekanan Ketaatan, Kompleksitas Tugas dan Pengalaman Auditor Terhadap Auditor Judgement. Jurnal Ilmiah Ekonomi Global Masa Kini, 9(2), 95-102.

Rahman, T., \& Solikhah, S. (2016). Analisis Pengaruh Rotasi Kerja, Motivasi Kerja dan Kepuasan Kerja terhadap Kinerja Karyawan di Lembaga Keuangan Mikro Syariah. Jurnal Muqtasid, 7(2), 23-49.

Riantono, I. E. (2018). Faktor-Faktor yang Mempengaruhi Audit Judgment. Jurnal Kajian Akuntansi, 2(2), 178-194.

Sari, D. I., \& Ruhiyat, E. (2017). Locus of Control , Tekanan Ketaatan dan Kompleksitas Tugas terhadap Audit Judgement. Jurnal Aset (Akuntansi Riset), 9(2), 23-34.

Sari, I. P. (2016). Pengaruh Gender, Tekanan Ketaatan, Kompleksitas Tugas, Pengalaman Auditor, Pengetahuan Auditor dan Kompleksitas Dokumen Audit terhadap Audit Judgement. JOM Fekon, 3(1), 2082022.

Saud, I. M., Heriyanto, E., \& Suryanto, R. (2018). Determinan Audit Judgment Auditor Pemerintah pada Audit Laporan Keuangan Pemerintah Daerah. Jurnal DInamika Akuntansi Dan Bisnis, 5(2), 195-208.

Sulistyawati, A. I., Santoso, A., \& Prastiti, D. S. (2019). Pengaruh Gender, Kompeksitas Tugas, Pengalaman Auditor, dan Kompetensi Profesional terhadap Audit Judgement. Jurnal Manajemen Bisnis Dan Inovasi, 6(1), 61-72.

Surya, L. P. L. S., \& Dewi, C. I. R. S. (2019). Pengaruh Tekanan Ketaatan pada Audit Judgment dengan Religiusitas sebagai Variabel Pemoderasi. EJurnal Akuntansi, 29(2), 673-682. 
Intan Bunga Pertiwi, Taufikur Rahman

Surya, L. P. S., Dewi, C. I. R. S., \& Yudha, C. K. (2018). Pengaruh Kompleksitas Tugas pada Audit Judgment dengan Variabel Religiusitas sebagai Pemoderasi. Aksioma Jurnal Riset Akuntansi, 17(2), 225-258.

JIAFR | 292

Suryaningsih, A. (2019). Pengaruh Komitmen Profesional, Independensi dan Religiusitas terhadap Penilaian Etis (Ethical Judgement) Auditor Pemerintah dengan Budaya Etis Organisasi sebagai Variabel Moderasi. Skripsi.

Wibowo, E. (2010). Determinan-Deteminan Penting dalam Auditor Judgement. Value Added, 6(2), 71-79.

William, \& Anton. (2019). The Effect of Task Complexity, Auditor Experience and Auditor Competence on Audit Judgement. Bilancia, 3(1), 99-109.

Yustrianthe, R. H. (2012). Beberapa Faktor yang Mempengaruhi Audit Judgement Auditor Pemerintah. Jurnal Dinamika Akuntansi, 4(2), 7282. 